Pogranicze. Studia Spoleczne. Tom XXIV (2014)

\author{
Pawel Plichta \\ Uniwersytet Jagielloński, KRAKów \\ E-MAIL: PAWEL.PLICHTA@UJ.EDU.PL
}

\title{
RODZINA WIZYTÓWKĄ MIASTA. PRZYPADEK KRAKOWA
}

Przestrzeń miasta $\mathrm{w}$ sposób immanentny jest zespolona $\mathrm{z}$ człowiekiem jako istotą tworzącą (homo faber) i symboliczną (animal symbolicum). Historia miast to bezsprzecznie dzieje ich mieszkańców, czy precyzyjniej rzecz ujmując, dzieje kolejnych pokoleń tychże mieszkańców, przekazujących międzygeneracyjnie kulturowe "geny” - tradycje, wartości, wzorce postępowania: „To jest właśnie ten najważniejszy kapitał, który dziedziczy się z pokolenia na pokolenie. Tradycje rodzinne" [Stuhr 2008: 8]. Istnieje wiele przykładów miast, których zwłaszcza włodarze wykorzystywali do partykularnych, municypalnych celów i czynią to nadal, nazwiska wybitnych fundatorów (między innymi Petersburg, Kazimierz) czy mieszkańców (rzeczywistych i fikcyjnych) z przeszłości, by wspomnieć takie fenomeny, jak: miasto Medyceuszy, Kopernika, Dawida, Proroka, Romea i Julii. Trudno nie zauważyć, że owe wybitne jednostki, żyją i tworzą w podstawowym dla człowieka środowisku rodzinnym (co w warstwie językowej ma też swój wyraz w określeniu „rodzinne miasto”). W tej perspektywie, również badawczej [Waksmund 2009; Wójs 2009; Kubicki 2010; 2012], ważne miejsce zajmuje Kraków jako między innymi miasto Jana Pawła II [Niedźwiedź 2006; Ziejka 2007: 7].

Konsumpcyjne zorientowanie współczesnej cywilizacji powoduje, że nawet w humanistyce są używane terminy i określenia „wyjęte” z podręczników skutecznego marketingu. Odżegnując się od tej stylistyki, proponuję zastosować wobec trzech rodzin, których dzieje splecione zostały mocno z Krakowem, termin „wizytówka” (aby uniknąć terminu „marka”). Przedstawiciele owych wybranych rodów, współczesnemu intelektualiście kojarzą się głównie z grodem Kraka jako ważnym ośrodkiem akademickim, kulturalnym i naukowym.

Dobrym źródłem do kulturoznawczej analizy współoddziaływania człowieka (ludzi) i miasta - jego genius loci, wydaje się specyficzny gatunek literatury, będący zgodnie z opinią Anthony’ego Giddensa „częścią refleksyjności nowoczesności” [Giddens 2001:20], pozostający na pograniczu autobiografii, biogra- 
fii, sagi [Bielas-Gołubowska 2011: 117; Tazbir 2000], czyli dzieje rodzin (rodów) napisane lub współtworzone przez ich członków [definicję klasycznego gatunku zob. Głowiński 1988: 454-455]. Dokumentacja rodzinnych doświadczeń i takaż perspektywa są współcześnie niezwykle ciekawym elementem badań w ramach historii kulturowej [Radomski, 2005]. Wgląd w „wielką historię” przez pryzmat świadków (ale też aktorów) zdarzeń z przeszłości („mała historia”) z jednej strony weryfikuje sądy i opinie zawodowych historyków, odsłaniając osobiste przeżycia, rozterki, psychologiczne i osobiste motywy podejmowanych decyzji, z drugiej zaś stanowi okazję do kreacji lub podtrzymywania rodzinnych mitów, uwieczniania tradycji wpisanych także w ów miejski kontekst [Ziejka 2007; Purchla 1992]. Krakowskie rodzinne sagi przyczyniają się też do spojrzenia z nieco innej, „prywatnej” perspektywy na kulturotwórczy wymiar niegdysiejszej stolicy. Można w ten sposób weryfikować opinie badaczy, jak choćby tę Ewy Chojeckiej, która, budując model kulturowej pamięci, twierdzi

to miasto buduje prestiż na pamięci swej starodawności oraz - do pewnego stopnia na ideach jednorodności narodowej i konfesyjnej. Doświadczył Kraków dwóch przywilejów: zachowania ciągłości substancji architektoniczno-urbanistycznej oraz ciągłości substancji swych mieszkańców - z jednym wszakże wyjątkiem: społeczności żydowskiej, której wysublimowany renesans pamięci oglądamy w ostatnich kilkunastu latach. Kraków funkcjonuje potocznie jako pars pro toto pamięci narodowej, a wynikające stąd zagrożenie nieznośnym patosem niweluje akcentami dystansującej się ironii i młodopolskiej groteski. Ta świadomość kulturalnej ciągłości, jakże rzadka w rozchwianej «Mitteleuropie», wydaje się istotnym wyznacznikiem krakowskiej lokalnej pamięci [Chojecka 2011: 80-82; por. Mikołajec 2007; Pochłódka 2008; Czabanowska-Wróbel 2011; Dybiec 2007; Kantor 1994].

Celem niniejszego artykułu jest przedstawienie rozpoznawalnych rodzin tworzących i pozostających w różnych aspektach symbolem (wizytówką) „Polskich Aten" [więcej podobnych i dla historii kulturowej istotnych symbolicznych określeń miasta, zob. Grodziska 2003]. Wywód zostanie oparty na analizie publikacji, które ukazały się w krakowskim Wydawnictwie Literackim, a dotyczą rodzin Estreicherów [Grzybowska 2010 - dalej skrót E; pierwsze wydanie: Grzybowska 1969], Stuhrów [Stuhr 2008 - dalej skrót S] i Zollów [Zoll 2011 - dalej skrót Z].

Główna przestrzeń miasta łączy trzy opowieści o tradycjach rodzinnych ludzi [zob. Boy-Żeleński 1967; Bieniarzówna, Małecki, Mitkowski 1979; Homola 1984; Mroczka 1999; Klich-Kluczewska 2005; por. także Demel 1957; Morawski 2011: 9], dla których dzieje Krakowa (we wszystkich tych przypad- 
kach przewijają się też ważne okresy lub epizody warszawskie) nie były tylko tłem, lecz którzy zaznaczyli w nich istotny ślad. Owe zatem ślady wybitnych „krakowskich” przedstawicieli trzech rodów na potrzeby niniejszego artykułu traktować można z perspektywy czasu jako swoistą wizytówkę miasta, które w różnych narracjach z przeszłości jawi się zarówno jako „Polska Jerozolima”, „Wielki Kraków” [por. Grodziska 2003: 117-137], „Rzym słowiański” [por. Burkot 2005; także: Ulewicz 1994; Grodziska 2003: 37-51] i jako „udawana stolica (...) Kozia Wólka, Woli Ogon lub Pipidówka!” [„Diabeł” 1912: 8; por. Kusek 2008; Homola Skąpska 1996, 1997].

Tylko w pierwszym przypadku „kronika” rodziny Estreicherów napisana została przez „człowieka pióra” - pisarkę Krystynę Grzybowską (1902-1963). W biogramach jest ona przedstawiana w kontekście rodzinnych genealogicznych więzi jako wnuczka historyka literatury Karola Estreichera, córka historyka prawa Stanisława Estreichera [Grodziski 1998] i Heleny z domu Longchamps, siostra historyka sztuki Karola Estreichera oraz żona prawnika Konstantego Grzybowskiego, matka historyka Stanisława Grzybowskiego i Teresy, żony Macieja Słomczyńskiego. Po trzydziestu latach (1999) od pierwszego pośmiertnego wydania dzieła Grzybowskiej w tytule pojawiło się bardziej rozpoznawalne nazwisko rodu, z którego pochodziła niż jej późniejsze po mężu, pod którym znana była jako autorka przede wszystkim literatury dla dzieci i młodzieży [Grzybowska 1950; 1957; 1959; 1960; 1961; 1962]. Autorem historii rodzinnych jest Jerzy Stuhr (ur. 1947) niegdyś student polonistyki Uniwersytetu Jagiellońskiego, ale przede wszystkim aktor, reżyser, scenarzysta, profesor sztuki [Stuhr 1992, 2007, 2012]. Nie przypadkiem tytuł jego publikacji przywodzi jednocześnie na myśl tytuł filmu Historie miłosne (1997, reż. J. Stuhr). Opowieść rodzinną napisał Andrzej Zoll (ur. 1942) były prezes Trybunału Konstytucyjnego, ombudsman, wybitny polski karnista, profesor Uniwersytetu Jagiellońskiego, wnuk Fryderyka Zolla młodszego (1865-1948).

$\mathrm{Na}$ uwagę zasługują formalne podobieństwa analizowanych dzieł o trzech znaczących dla krakowskiej i polskiej kultury rodach. Wszystkie podkreślają tę orientację przez zastosowaną formę liczby mnogiej „-owie” i przymiotnik „rodzinna” lub „rodzinne”. Charakterystyczną cechą dzieł pisarki, aktora i prawnika jest ich autobiograficzny rys ze specyficzną autokreacją i/lub określaniem własnej tożsamości w rodzinnym kontekście. Według Lejeune’a konstruowanie tożsamości to właśnie „swoista misja” autobiografii [Lejeune 2007: 18; por. Obarska 2008: 146]. W najbardziej oczywisty sposób autobiograficzny zamysł ujawniał się w pierwszym Moja rodzina, czyli galeria Zollów [Z: 7-238] i czwartym rozdziale opowieści rodzinnych: Moja działalność publiczna [Z:339502]. Ten aspekt sprawia trudność w przyporządkowaniu gatunkowym ana- 
lizowanych dzieł. Biografie (pisane przez osoby bliskie biografom, dotyczące osób im bliskich [por. Cieński 1992: 34]) i autobiografie bowiem, według wielu literaturoznawców, są „tak od siebie odległe, że w istocie stanowią coś całkiem innego" [Cieński 1992: 39]. W analizowanych przypadkach rzecz ma się dokładnie odwrotnie. Zaangażowanie autorów uwidacznia się nie tylko w podejmowanych tematach (wskazywanie u antenatów podobieństw i wyjaśnień dla swojej kondycji, cech charakteru, działalności publicznej i osiągnięć życiowych), ale przede wszystkim w warstwie językowej (często stosowane zaimki dzierżawcze „mój, moja”). Więź z przeszłością i chęć nawiązywania do tradycji wyrażają oni w warstwie ikonograficznej przez zestawienia na okładkach starych fotografii $z$ archiwów rodzinnych oraz fotografii autorów w towarzystwie najbliższych. Jedynie w kolejnym wydaniu Estreicherów (2011) na okładce wykorzystano fotografię autorki jako dziecka z ojcem Stanisławem i rodzeństwem Ewą i Karolem. Wszystkie publikacje wzbogacają liczne archiwalne fotografie przedstawiające przede wszystkim bohaterów opowieści, ale też miejsca i rzeczy ważne dla rodzinnych tradycji. Trzy sagi zawierają również drzewa genealogiczne opisywanych rodzin.

Zastanawiającym faktem są różne terminy użyte w podtytułach rodzinnych monografii: „kronika”, „historie”, „opowieść”. Mimo że autorzy, odwołują się do źródeł ${ }^{1}$, starają się weryfikować podawane informacje, finalnie - co nie umniejsza ich walorów poznawczych - nie są to prace stricte naukowe. Brak na przykład precyzyjnych przypisów do cytowanych fragmentów, niekiedy autorzy przyznają się do fantazjowania lub podchodzą do źródeł instrumentalnie i fragmentarycznie [por. E:283]. „Czy historia moich pradziadków tak się właśnie toczyła? Być może. (...) próbuję snuć i odtwarzać życie przodków” [S:39-40].

Istotnie, narracyjna perspektywa historyczna (oparta na wspomnieniach, pamiętnikach, listach, dokumentach) dominuje we wszystkich przypadkach, choć nie brak także wątków o charakterze filozoficznym, moralizatorskim, refleksyjnym i interpretacyjnym samych autorów [o znaczeniu dokumentów autobiograficznych pisał już w latach dwudziestych XX wieku Florian Znaniecki; zob. Znaniecki 1970]. Dzieła dedykowane są lub pisane były z myślą o najmłodszym pokoleniu, explicite: „Mam nadzieję, że dopiszą do historii naszej rodziny nowe interesujące rozdziały. Żeby im to ułatwić, wnukom [Fryderykowi i Andrzejowi] właśnie dedykuję tę książkę” [Z:228; por. Z:5]; „To dla nich [syna

\footnotetext{
We wszystkich omawianych przypadkach dostępne są niepublikowane lub publikowane pamiętniki, wspomnienia przedstawicieli rodzin [zob. Estreicherówna 1936, 1968, 1999; Estreicher 2001, 2002, 2003, 2004, 2006, 2013; Zoll 2000]. Pomocne okazały się też: pamiętnik Oskara Stuhra pisany od 1939 roku; pamiętnik Marii z Niemczewskich Zollowej, notatnik Fryderyka Zolla młodszego.
} 
i córki] i ich dzieci rekonstruowałem historię naszej rodziny (...) by przechowywana przeze mnie wiedza przetrwała w następnych pokoleniach, niezależnie od miejsca, gdzie zapuszczą korzenie" [S:7]. W przypadku niedokończonego dzieła Krystyny Grzybowskiej, według jej syna, opowieść o rodzinie stanowi jej „dług spłacony korzeniom własnej twórczości i własnej osobowości” [Grzybowski 2010: 462].

Cechą tego typu literatury jest z konieczności jej fragmentaryczność, podobnie jak pamiętnikarze, także autorzy „historii rodzinnych” koncentrują się bowiem i utrwalają, jak wskazywał Michał Głowiński, „osobliwości miejsca i czasu” [Głowiński 1997: 148], a „to, co jest czytelnikowi znane, czy z innych relacji czy z bezpośredniego doświadczenia, nie jest już godne zapisywania, choćby stanowiło istotny składnik osobistego losu” [Głowiński 1997: 148-149; por. S:103].

Silny związek dziejów analizowanych rodzin z Krakowem sprawia, że stają się one w jednej z warstw również narracjami o mieście. Słusznie zauważył Jerzy Korczak, że „dzieląc los miasta, wrastali w polskość: w latach następnych ta polskość miała iść z nimi z pokolenia na pokolenie" [Korczak 2000: 8]. Kategoria polskości tak silnie utożsamiana $\mathrm{z}$ Krakowem ma we wszystkich przypadkach specyficzny - jagielloński rys, różnorodności i tolerancji. Do tego starego modelu współżycia mieszkańców o różnych przekonaniach nawiązywali zarówno Andrzej Zoll, jak i Jerzy Stuhr. Kilka wspólnych cech, dzięki silnym związkom trzech rodzin z Krakowem, stało się ważnymi elementami rodzinnych tradycji, a współcześnie może być odczytywanych jako doświadczenia wielu innych inteligenckich rodzin krakowskich, których dzieje rozpoczynają się w XVIII/XIX wieku wraz z przybyciem i/lub decyzją o pozostaniu w grodzie Kraka.

Fenomen polonizacji cudzoziemców, którzy przybyli i wybrali Kraków na miejsce życia i „zapuszczenia korzeni” to historia asymilacji, „próba wtopienia historii rodziny w historię miasta" [S:40]. Ten fenomen kwestionuje jeden z polskich mitów i stereotypów o „rdzenności polskości” mierzonej „narodowym termometrem” [Korczak 2000; por. Zoll, 2011:4]. Zwrócił na niego uwagę Janusz Tazbir w recenzji wznowionego wydania Estreicherów, pisząc: „Tak silnie zagrożonej w dobie zaborów polskości przybyły zgoła niespodziewane a nader cenne posiłki w postaci asymilujących się potomków obcych rodzin, bez których nie sposób sobie wyobrazić rozkwitu naszej kultury" [Tazbir 2000: 26]. Janusz Miliszkiewicz, przypominając zasługi rodu Estreicherów, pytał zaś retorycznie: „Czy w dziejach Polski istniała druga taka rodzina, w której tak precyzyjnie $z$ pokolenia na pokolenie przekazywano narodowe tradycje, inteligenckie mity i złudzenia?” [Miliszkiewicz 2009: 30]. I dalej: „Rodzinna tradycja Estreicherów koncentruje się wokół Uniwersytetu, wokół nauki, wo- 
kół wolności” [Miliszkiewicz 2009: 31]. Tazbir, podsumowując kronikę „,jednej rodziny obcego pochodzenia i bezherbowej (do nadanego w 1881 roku przez Franciszka Józefa szlachectwa nie przywiązywano tam większej wagi)", stwierdza, że to przypadek rodziny „bardziej krajowi zasłużonej od niejednego rodu magnackiego!" [Tazbir 2000: 26]. Istotnie, wszystkie trzy rodziny to przykłady krakowskiej inteligencji ${ }^{2}$, dla których „wartości kulturalne i artystyczne były szczytem i prawem" [E:109]. Protoplaści rodów przybyli do Krakowa z różnych stron, obierając to miasto za swoje i sukcesywnie zapuszczając w nim korzenie dla następnych pokoleń. Jerzy Stuhr stwierdził wprost: „Nie trzeba pokoleń, herbów i szlacheckich rodowodów, żeby czuć lojalność w stosunku do ziemi, na której się mieszka. Moja rodzina jest typowym tego przykładem. Zawsze miałem poczucie silnego mieszczańskiego zakotwiczenia $\mathrm{w}$ byt galicyjski” [S:6]. Za Stanisławem Tarnowskim, fenomen polonizacji, czyli zmiany „przybyszów z państw zaborczych w gorących patriotów, oddanych całkowicie sprawom swojej nowej ojczyzny" Andrzej Zoll wiąże z wielką siłą przyciągania tego kawałka ziemi i rolą kobiet [Z:16]. Żony i matki miały decydujący wpływ nie tylko na zmianę języka (z niemieckiego na polski) ale też wyznania (np. ewangelicko-augsburskiego na katolickie) $)^{3}$, które wpisywały się w proces swoistego „wrastania” wyrażający się w wielu innych symbolicznych gestach, utwierdzających i formujących rodzinną tożsamość [o dziejach rodzin o niemieckich korzeniach; zob. Röskau-Rydel 2011].

Opowieść Jerzego Stuhra rozpoczyna się w 1879 roku od znaczącego wątku - wyboru Krakowa przez jego pradziadka Austriaka Leopolda Stuhra na miejsce zamieszkania wraz z właśnie poślubioną Anną Thill. Jedno z miast monarchii austro-węgierskiej jawi się w wyobrażonej [przykład kontrolowanej imaginacji Stuhra - biografisty ${ }^{4}$ żałującego, że w dokumentach archiwalnych

2 Jerzy Stuhr z emfazą podkreślał to swoje rodzinne inteligenckie pochodzenie także w innym miejscu, pisząc: „tradycja jest to pewien zespół wartości i pryncypiów zamkniętych w jakimś niepisanym kodeksie. Wartości i pryncypiów do przestrzegania (...). Są to wartości zarówno etyczne, jak i estetyczne - bardzo ważne. To jest taki kodeks do przestrzegania dla samego siebie. (...) Tylko ja, inteligent, z mej dyscypliny się rozliczam. (...) jestem inteligentem i wiem, co zawsze w swym postępowaniu stawiałem na piedestale - lojalność w stosunku do kogoś, komu coś obiecałem, przyrzekłem, etos pracy i nobilitacja przez pracę, dążenie do czystości sumienia, nienaruszanie czyjegoś obszaru prywatności (...), obowiązek przechowywania i otoczenia opieką pamiątek i mienia rodzinnego, nieobmawianie innych. (...) żadnego zewnętrznego i wewnętrznego «rozmemłania»" [Stuhr 2012: 49-51; 176].

3 Na marginesie warto zaznaczyć, że zjawisko to było już przedmiotem szczególnej refleksji i nauczania starożytnych izraelskich proroków, rygorystycznie potępiających zawieranie małżeństw egzogamicznych. Zagrożenie dla tożsamości i jednorodności kulturowej i religijnej widzieli właśnie w braniu za żony obcych nieizraelskich kobiet.

4 Postulat Andrzeja Cieńskiego: „bo biograf musi próbować mówić prawdę” [Cieński 1992: 38]. 
nie ma emocji czy przeżyć, por. S:39-40] konwersacji przodków jako miejsce z potencjałem, przedstawiane w ówczesnej wiedeńskiej prasie jako „magnes Galicji” [S:10]. Za osiedleniem się młodych małżonków w „polskim Rzymie” [S:10] znacząco i rozstrzygająco przemawiał argument, że „Kraków był tańszy od Wiednia, czy nawet Brna" [S:11] i bezpieczniejszy z uwagi na konserwatywne nastroje [por. S:12]. Dzieje tętniącego życiem, nawet mimo wiedeńskiej perspektywy, miasta przypominają przywołane fakty: wdrażanie reform miejskich prezydenta Józefa Dietla, rozbudowa kolei, aranżowanie parków miejskich, połączenie linią tramwajową Podgórza z dworcem kolejowym, ponaddziesięciotysięczny przyrost mieszkańców, powstanie Akademii Umiejętności, wizyta cesarza Franciszka Józefa „wielkiego księcia Toskanii i Krakowa”, proces Ludwika Waryńskiego. Decyzja protoplastów rodu „o wyborze Krakowa na miejsce do życia" dotyczyła w istocie spodziewanych potomków. W drugim pokoleniu dla Rudolfa, Oskara i Leopolda „galicyjska ziemia mówiąca po polsku była ojczyzną" [S:57].

Obiektywne fakty dowodzą, że malarz Dominik à Paulo Österreicher do Krakowa przybył z Igławy na Morawach przez Wiedeń, Rzym i Warszawę. Krystyna Grzybowska również pozwoliła sobie na snucie domysłów, jak ten o fizjonomicznym dziedzictwie: „Dominik przekazał swej rodzinie wciąż powracający typ śródziemnomorskiej urody. Nie mam na to dokumentów, puszczam wodze fantazji, wyciągam wnioski z rodzinnych temperamentów" [E:111]. Także w przypadku Österreicherów szybkie wejście w mieszczańską inteligencję oznaczało równie dynamiczną ich polonizację. „Syn Dominika od dziecka będzie czuł się Polakiem. A ów, zdaniem wnuka «Niemiec» Dominik będzie się zastanawiał po śmierci żony, czy na grobie jej nie położyć napisu w polskim języku. Odradzi mu to jednak córka Klara” [E:114]. Grzybowska realistycznie także stwierdziła wprost: „Rozalia i Dominik pozostali Niemcami, (...) ale jednocześnie, dzieląc los miasta, w którym od przeszło ćwierć wieku mieszkali, stali się przede wszystkim krakowianami” [E:171]. Drugie pokolenie przybyszów wrosło w miasto i „nie dziwiło rodziców wcale, że obydwoje [Klara i Alojzy] od małego polski język uznali za najważniejszy, pierwszeństwo mu dają przed niemieckim w rozmowie ze wszystkimi. Prócz rodziców oczywiście" [E:172].

Uderzającym symbolem, wyrażającym zmianę tożsamości rodowej są dwa zestawione ze sobą „lingwistyczne” fakty - list Stanisława - ojca autorki Kroniki rodzinnej, napisany z konieczności w języku niemieckim z obozu koncentracyjnego w Sachsenhausen do rodziny w Krakowie oraz decyzja Alojzego, którą podjął sto trzydzieści lat wcześniej. Polecił on wyrycie na grobie ojca Dominika Österreichera inskrypcji w języku polskim i podpisał się na dokumencie zgonu 
jako Estreicher, czym „zdecydował o polskości rodziny” [E:217]. Polska tożsamość Alojzego potwierdzona została mianowaniem go profesorem historii naturalnej i botaniki [por. E:219].

Protoplaści rodu Zollów przebyli drogę z Illingen koło Stuttgartu do Krakowa przez Myślenice, Bochnię, Wieliczkę i Podgórze, gdzie Katarzyna z Wątorskich i Józef Christian Zollowie kupili dom na rogu ulice Limanowskiego i Józefińskiej. Podobnie wybór Podgórza postrzeganego jako tradycyjnie bardziej tolerancyjne i otwarte miasto niż Kraków i zakup tam kamienicy na rogu ul. Wiślanej 1 (później zmienionej na ul. Celną) zdecydował o karierze potomków rodziny Stuhrów. Kamienica stała się dla Stuhra prawdziwym symbolem „zakorzenienia w tym mieście” [S:175]. W krakowskich opowieściach rodzinnych to dom zatem staje się miejscem szczególnie mocnego zakorzenienia i przyciągania $\mathrm{z}$ różnych stron świata członków rodzin. Punktem orientacyjnym w rodzinnej przestrzeni miejskiej dla kolejnych pokoleń była pamięć o wcześniejszych siedzibach, na przykład pałacu Steinkellera przy ul. św. Tomasza, w którym zamieszkali Anna i Leopold Stuhrowie wraz z Weroniką Thill (młodszą siostrą Anny), ich restauracji w kamienicy na rogu ul. Kolejowej (dziś ul. Westerplatte) i Lubicz. Dla Zollów kolejne rodzinne centrum mundi stanowiła przez lata kamienica przy ul. Studenckiej 25 zakupiona przez rozpoczynającego w 1897 roku karierę uniwersytecką w „ukochanym Krakowie” Fryderyka młodszego. „W tym domu aż do 2008 roku toczyło się życie kolejnych pokoleń naszej rodziny. A i ja sam mieszkałem tam blisko pięćdziesiąt lat" [Z:79, por. 184] wspominał autor-prawnik. Biograficzną prezentację członków rodu Zollów ich autor zakończył konstatacją podkreślającą silny symboliczny walor domu dla rodzinnej tożsamości: „Koło się zatoczyło. (...) dzisiaj (...) mieszkamy w Konarach w gminie Mogilany (...) Z tego miejsca z góry patrzymy na Kraków, ale z poczuciem bardzo ścisłego związku z tym miastem i przede wszystkim z jego uniwersytetem" [Z:238].

Dominik Österreicher za namową przyjaciela Hugona Kołłątaja kupił w Krakowie przy ul. Szczepańskiej (obecnie pl. Szczepański) dwupiętrową pojezuicką kamienicę, do której sprowadził z Igławy żonę Rozalię [por. E:159-160]. Małżeństwo, rozmawiając i pisząc nadal po niemiecku, z czasem stało się rodziną wielokulturowego miasta. „Tu stał ich dom, obszerna i porządnie utrzymana kamienica" [E:171]. Podobnie siłę oddziaływania miała też kamienica przy ul. Sobieskiego i dom babki autorki przy ul. Batorego. Przez wiele lat domem Alojzego Estreichera był Ogród Botaniczny - jego dzieło, efekt połączenia osobistej pasji botanika, zdolności organizatorskich i zaangażowania na rzecz środowiska akademickiego. Dzięki jego wysiłkom od 1824 roku placówka, zgodnie 
z opinią Władysława Szafera, należała do „najbogatszych wówczas ogrodów botanicznych w Europie" [E:224].

Drugim symbolicznym miejscem wiążącym losy przybyłych z konkretną przestrzenią i losami miasta były cmentarze. Dla Stuhrów rodzinny grobowiec na cmentarzu Rakowickim, w którym jako pierwsza pochowana została w 1884 roku Weronika Thill, przypieczętował wcześniejsze decyzje. Autor przypuszcza w tym kontekście: „bo może rzeczywiście jest tak, że w miejscu, w którym rodzą się nasze dzieci i w którym odchodzą nasi najbliżsi, łatwiej zapuścić korzenie?” [S:32]. Podobnie ów związek widziała Grzybowska: „z krakowską ziemią zmieszały się prochy ich dziesięciorga dzieci" [E:171-172]. We wspomnieniu pośmiertnym o ostatnim z dynastii Estreicherów - Karolu, Ewa Owsiany przypomniała ostatnie słowa dedykacji profesora „Proszę pamiętać o Krakowie! Bitwa o Kraków trwa!” i jednocześnie skonstatowała: „Miasto stoi na jednym więcej grobie" [Owsiany, 1996:5]. W przypadku Zollów ten aspekt zakorzenienia miał miejsce na starym cmentarzu podgórskim [Z:23, 131], a później także Rakowickim [por. Z:84, 95].

Przedstawiciele kolejnych pokoleń rodzin Zollów i Estreicherów związali swoje losy z najbardziej rozpoznawalną instytucją Krakowa - Uniwersytetem Jagiellońskim. W przypadku rodziny Stuhrów - krakowska kariera akademicka oznaczała ukończone studia prawnicze, polonistyczne lub psychologiczne w jagiellońskiej wszechnicy a znaczący sukces związany został z Wyższą Szkołą Teatralną im. Ludwika Solskiego, której autor Tak sobie myślę.. był profesorem i rektorem.

Wspólnym dramatycznym doświadczeniem akademickiego Krakowa [„pierwszy wojenny szok” S:101] i uniwersyteckich rodzin był dzień 6 listopada 1939 roku. Wydarzenie, które przeszło do historii jako Sonderaktion Krakau, przywodzi na myśl brutalny i barbarzyński atak okupanta nazistowskiego na najbardziej czuły, bo kulturowy, nerw podbijanego kraju i społeczeństwa ${ }^{5}$. Akcja aresztowania profesorów głównie Uniwersytetu Jagiellońskiego (choć byli w tej grupie także uczeni innych krakowskich szkół wyższych [zob. „Alma Mater" 2009, s. 19, w numerze specjalnym periodyku także wspomnienia i materiały dotyczące akademickiej tragedii uczonych]) stanowi jeden z kluczowych elementów kulturowej pamięci kultywowanej także i współcześnie przez środowisko $^{6}$. Tymi krakowskimi wydarzeniami właśnie rozpoczęła swoją opowieść

5 Warto dodać, że wspomnienia-świadectwa tego tragicznego dla krakowian, ale przede wszystkim nauki i kultury polskiej wydarzenia, były dokumentowane właśnie dzięki relacjom ich uczestników [zob. Konopczyński 1945; Urbańczyk 1946; 1969; Landau 1962; Gwiazdomorski 1964a; Pigoń 1966; Starachowicz 2012; por. Piwarski 1946: 66-93].

6 Społeczność Uniwersytetu Jagiellońskiego tradycyjnie obchodzi 6 listopada jako Dzień Pamięci. 
Krystyna Grzybowska, rekonstruując 9 lutego 1940 roku - piątek, w którym do Krakowa z niemieckiego obozu koncentracyjnego Sachsenhausen-Orienburg powróciła grupa ponad stu „starszych” (w wieku powyżej czterdziestu lat życia) profesorów [E:7]. Nie było w wśród nich ojca autorki profesora Stanisława Estreichera, który „W okropnych cierpieniach” [Z:302] zmarł 28 grudnia 1939 roku w obozie. Wśród aresztowanych był Fryderyk Zoll młodszy, który podobnie jak wielu jego ocalałych kolegów zaproszonych do sali Collegium Novum, pozostawił relację świadka wydarzeń [zob. Z:294-308]. Zaangażowanym świadkiem tych zdarzeń był także Oskar Stuhr, który kilka dni później, 9 listopada 1939 roku, został aresztowany i osadzony w więzieniu przy ul. Montelupich, następnie przewieziony do Nowego Wiśnicza, a w czerwcu 1940 do Oświęcimia [por. S:101-116]. „Blisko Krakowa. Wyjdziemy stamtąd żywi” [S:116] zapisał w swym pamiętniku nadzieje wielu towarzyszy niedoli Oskar Stuhr, który dzięki staraniom rodziny został zwolniony z oświęcimskiego obozu.

Dzieje uczelni - jej sukcesy, porażki i dramaty - to $\mathrm{w}$ równym stopniu dzieje konkretnych ludzi, utrzymujących z instytucją nie tyle formalny stosunek pracy i sposób zarobkowania, ale poczuwających się do odpowiedzialności za kultywowanie tradycji krakowskiej wszechnicy i za jej przyszłość. Przedstawicielka rodu Estreicherów, podkreślając ów związek i trwanie rodziny wiernej miastu i uczelni, zauważyła w tym kontekście: „Rzecz charakterystyczna, z nią [uczelnią] idzie w górę i z nią upada" [E:214]. Z ambitnym dziełem Kołłątajowskiej reformy Szkoły Głównej Koronnej od początku związany był Dominik - niegdysiejszy towarzysz włoskich peregrynacji „zuchwałego, płochego i prędkiego" [E:141] kanonika krakowskiej kapituły Hugona. Odmowa stanowiska w katedrze bibliografii dla Karola Estreichera, jakkolwiek krzywdząca dla zainteresowanego, przeżywana była przez niego jako zerwanie dobrej tradycji i więzów łączących bibliotekę z Uniwersytetem: „Ale mnie szło o utrzymanie tradycji. Nie trzymałam się ustawy, lecz trzymałem się Senatu (...). Tym sposobem rządowa biblioteka była zawsze Jagiellońską..." [E:428-430].

Działalność naukowa podporządkowana służbie publicznej w przypadku Zollów była realizowana $\mathrm{w}$ różnych obszarach (leśnictwo, organizacja pracy, archeologia) i miejscach, ale plan pierwszy zajmuje bezsprzecznie prawo i krakowski uniwersytet. Do dwóch wielkich przodków Fryderyka starszego zwanego Rzymianinem, Fryderyka młodszego „Cywilisty” dołączył także dzięki umiejętności pogodzenia dwóch aspektów własnej działalności (naukowej i publicznej) - autor opowieści rodzinnych - Andrzej Zoll. Pierwszy z rodu Zollów profesor prawa, rektor UJ, postulował i realizował z powodzeniem własną metodę wykorzystania fundamentu cywilizacji europejskiej - prawa rzymskiego. Fryderyk młodszy „Cywilista”, podchodząc do zagadnień praw- 
nych kierował się przede wszystkim pragmatyzmem, co oznaczało skupienie się na „celu, któremu dana instytucja prawna miała służyć” [Z:279; por. Gwiazdomorski 1964]. W obszernej części sagi rodzinnej, analizując własną działalność naukową i publiczną autor dał wystarczające argumenty, by stanąć ze swymi przodkami w gronie osób nie tylko z krakowskich katedr uniwersyteckich kształtujących polską kulturę prawną [Uruszczak 2007].

Przedstawiciele kolejnych pokoleń niekiedy musieli potwierdzać swoimi życiowymi decyzjami wybór Krakowa jako swojego miasta. Tak było w przypadku Andrzeja Zolla, który zdecydował po maturze wyjechać z Warszawy i rozpocząć studia na najstarszym polskim uniwersytecie. „Była to decyzja pod każdym względem bardzo dobra. Kraków mnie zmobilizował" [Z:180]. W tym przypadku Kraków to także metonimia konkretnych profesorów, którzy byli uczniami jego dziadka, naukę przekazywali „w najlepszym stylu” [Z:181], a przykładem wysokiej kultury osobistej formowali młodego adepta prawa. „Nie mogłem się kompromitować. Zabrałem się więc solidnie do nauki i przystępowałem do egzaminów rzeczywiście przygotowany" [Z:180] - przyznał w autobiograficznych fragmentach późniejszy prezes Trybunału Konstytucyjnego.

Oswajanie nowego wybranego miejsca (w przypadku Jerzego Stuhra także Bielska-Białej, gdzie spędził dzieciństwo) oznaczało zmaganie się z pozorną obcością, wynikającą z faktu posiadania niemiecko brzmiącego nazwiska. Niemieckie nazwiska skłaniają do wyraźnego poczucia własnej tożsamości. Każda z analizowanych publikacji zawiera epizod związany z niemiecko brzmiącym, czyli dla stereotypowo myślących Polaków, obcym nazwiskiem. Szkolne awantury z kolegami we wspomnieniach Jerzego Stuhra z Bielska-Białej miały taki właśnie podtekst: „moją agresję budził fakt wykluczenia mnie z różnych grup z powodu niemiecko brzmiącego nazwiska (...) ja to czułem osobiście, że na mnie krzyczano «Niemiec»" [S:182-183; por. Stuhr 2012: 20-21]. Grzybowska przywołała nieudaną do końca próbę „oswojenia” rodowego nazwiska przez jego podwojenie Estereicher-Rozbierscy, podjętą za namową Antoniny przez jej syna, Karola [por. E:101]. Z kolei w autobiograficznej części Andrzej Zoll wspominał zajście, jakie miało miejsce w czasach jego pracy w Państwowej Komisji Wyborczej w trakcie wyborów parlamentarnych w 1991 roku. Demonstrujący swoje niezadowolenie z decyzji PKW zwolennicy partii X (Stanisława Tymińskiego) „nieśli transparent z pytaniem: «Zoll, kto ty jesteś?»” [Z:447]. W dziejach rodzin, których przodkowie na swoją małą ojczyznę wybrali polski Kraków pojawia się to doświadczenie „inności”, które wpłynęło na praktykowanie postawy szacunku, tolerancji, otwartości. Rodzinne doświadczenia i tradycje w oczywisty sposób dochodzą do głosu w diagnozie współczesnego 
społeczeństwa polskiego: „Cięgle jeszcze w naszej mentalności zakorzeniony jest podział na «my» $\mathrm{i}$ «oni». Bardzo to osłabia nasze siły" [Z:501].

Ścisły związek rodów Estreicherów, Stuhrów i Zollów z Krakowem wymagał od autorów trzech sag rodzinnych zarysowania jego charakterystyki - nawet jeśli opis „wyczarowuje przeszłość” miasta.

Niegdyś gród monarchów, serce ojczyzny - zmienił się w ich grób (...). Była to wtedy [w 1787 roku - dop. P.P.] malutka mieścina. (...) Miało jednak miasto rodzaj powabu, którego dziś nie doznajemy: przy szczupłej liczbie osób wszyscy znali się ze sobą i żyli jako członkowie jednej rodziny. Bez odosabniania się mniszego, bez nadętości pawiej, bez cudzoziemskiego języka. (...) Były ówczas w Krakowie domy gościnne, staropolskie lub za staropolskich domów przykładem otwarte" [E:134-138].

Przyjazd Antoniny Rozbierskiej do Krakowa, miasta jej męża Alojzego, został odmalowany z realistycznymi szczegółami:

Gdy przejeżdżali przez miasto, entuzjazm jej osłabł wobec fetoru bijącego z zaułków i stosów śmiecia. Nadto Kraków wydał się jej zrujnowany, ale strzegła się zdradzić $\mathrm{z}$ rozczarowaniem, wiedząc, że mąż jest gorącym wielbicielem rodzinnego miasta" [E:253].

W swoim dzienniku Lucynka Kraśnicka komentowała wydarzenia 1848 roku:

Gdyby nie Opatrzność, co nad nami czuwa, Kraków, stolica Piastów i Jagiellonów, ten pomnik dawnej świetności, grobowiec naszych królów, miejsce tak drogie, tak święte dla każdego Polaka - ten tedy Kraków leżałby dziś zagrzebany w gruzach lub stał się był pastwą płomieni... [E:309].

Na początku lat dziewięćdziesiątych XIX wieku (...). Do Krakowa i ościennego Podgórza, Ludwinowa czy Łobzowa ciągnęli ludzi mający trochę grosza, którym marzyło się robienie własnego interesu w warunkach względnej stabilizacji. Kraków wszak, nie Poznań czy Warszawa, był uznawany za ostoję wolności. (...) Wystarczyło więc, by przyjeżdżający do Krakowa miał choć trochę szczęścia w interesach, a wkrótce stawał na nogi i wówczas szybko pojawiała się u niego potrzeba posiadania nowego mebla czy zmiana wystroju wnętrza [S:43-44].

Kolejnymi elementami podtrzymującymi rodzinne tradycje, przywołującymi opowiadane i budujące narracje były we wszystkich trzech przypadkach rzeczy zarówno te użyteczne, praktyczne, wartościowe, jak i te jedynie mające wartość sentymentalną bibeloty, a nawet zupełnie bezużyteczne gromadzone jednak w szufladzie z napisem „rzeczy na nic już niepotrzebne”, jak klucze, 
które „już niczego nie zamykały” [E:448]. We wspomnieniach przywołane jest też wydanie in folio Pana Tadeusza z ilustracjami Michała Elwiro Andriollego, „które wówczas musiało się koniecznie znajdować w każdym domu mającym pretensje do kultury i zamożności” [E:446]. Krystyna Grzybowska, konkludując przemyślenia nad "tyranią mebli”, stwierdziła, że są rzeczy, z którymi liczymy się "tylko ze względu na ludzi, których nam przypominają” [E:106]. $\mathrm{W}$ istocie rodzinne wspomnienia nie mogą obejść się bez przywołania, opisu, fotografii, wskazania niczym muzealnych eksponatów, rzeczy przywodzących ciągle swoich użytkowników lub autorów. Ważnym elementem kultury pamięci i transmisji tradycji są artefakty wymagające choćby minimalnej wrażliwości kolekcjonera [por. E:106-107]. Domowe muzeum Estreicherów, kryjące rodzinne symboliczne pamiątki-skarby (bilet wizytowy Adama Mickiewicza, stare zegarki, pomadki od króla Stanisława Augusta Poniatowskiego, złoty medal „Merentibus”, pierścień Alojzego), stanowił staroświecki kantorek. Podobnie nieocenioną wartość miał stolik zrobiony przez Dominika jako drugi po wykonanym wcześniej darze dla ostatniego polskiego króla. Skoncentrowany na rzeczach był również Jerzy Stuhr, w roli biografa wskazujący czytelnikowi: modlitewnik przywieziony przez Annę ze Schrattenbergu do Krakowa, serwis z podobizną (fotografia Szymona Balicera) Anny i Leopolda prezent z okazji narodzin pierworodnego Rudolfa, serwantkę zakupioną u Stefana Iglickiego. Hanna M. Karpińska tłumaczyła wprawdzie dbałość o przedmioty aktorskim „wyczuleniem na rekwizyty” [Karpińska 2009:45], ale detale z uwagą przywołuje także w swej opowieści profesor prawa, co widać znacząco przekracza przywiązanie autorów do swych profesji.

Wartością krakowskich wielopokoleniowych domów rodzinnych były we wszystkich trzech przypadkach obrazy przodków. Portrety prapradziadka Dominika i praprababki Rozalii towarzyszyły kolejnym pokoleniom Estreicherów. Portret Anny i Leopolda Stuhrów znalazł swe miejsce w jednym z krakowskich teatrów, obecnie wisi w foyer teatru STU przy al. Zygmunta Krasińskiego.

Przedstawiciele omawianych rodów, żyjąc i tworząc w Krakowie, pozostawili po sobie rozpoznawalne dzieła. Dla Estreicherów (Karola starszego, Stanisława i Karola młodszego) monumentalnym dziełem w skali kultury polskiej jest rzecz jasna Bibliografia polska. Prace nad nią rozpoczął Karol w 1848 roku, a wydawana była od 1869 roku. Wnuczka bibliografa zaznaczyła, że nie tylko patriotyzm, ale także „poczucie solidarności z innymi pracownikami nauki, społeczny instynkt” [E:280] przynaglały jej dziadka do żmudnej pracy nad jego opus vitae i jak się okazało także rodzinnym opus magnum. W twórczości i działalności nie bez znaczenia pozostawały rodzinne tradycje i pasje przodków. Wielce pomocne było w przypadku kolejnych Estreicherów bibliografów 
obcowanie od dziecka z metodą przyrodniczą, pozwalającą zbierane okazy owadów opisywać, klasyfikować, katalogować. „Syn rósł pod promieniowaniem tej pasji. Zmienił w niej tylko przedmiot, a nie formę, nie metodę. Druki więc - a nie owady, książka - nie ogród" [E:283]. Zagrożeniem dla przedsięwzięcia, które kończył jego syn, był wybuch II wojny światowej, a szczególnie konsekwencje zapowiedzianego na 6 listopada 1939 roku odczytu Czym jest niemiecka nauka. Pasjonujące, choć wykraczające poza ramy niniejszego artykułu, są przekazane przez Grzybowską dzieje Biblusi, Biblii lub Zeci [por. E:36], jak w szyfrowanych listach określali ostatni tom Bibliografii jej wojenni opiekunowie.

Wśród wszystkich trzech autorów powraca świadomość i uznanie dla rodzinnego międzygeneracyjnego przekazu tradycji, także tych lokalnych.

Babka była dzieckiem Krakowa. (...) wyraźnie chciała przekazać mu [Karolowi, bratu Krystyny] tradycje i wszczepić zamiłowania, które podziwiała u swego ojca [Ambrożego Grabowskiego]. Podziwiała jego zalety i stawiała nam jako wzór. Chlubiła się jego chłopskim pochodzeniem ze wsi Głębowice pod Kętami. (...) opowiadała, że przyszły uczony i właściciel domu do Krakowa przyszedł jako mały chłopiec, na bosaka, szukając chleba [E:449].

Na znaczenie klimatu i atmosfery rodzinnego domu zwrócił uwagę również Zoll: „Moje dziecięce i młodzieńcze życie przebiegało pod bardzo silnym wpływem tragedii narodowej i rodzinnej. Moja matka nie mogła się pogodzić ze stratą dwóch synów" [Z:343].

Innym symbolicznym zespoleniem z lokalnością i tradycją okazał się wybór imion (w rodzinie Zollów akt ten to jedna z symbolicznych rodowych tradycji) dla dzieci Karola Estreichera. Trzecia jego córka Wanda Maria Regina otrzymała imiona podobnie jak wcześniej jej siostry „polskie i krakowskie”, jak zapisał w dzienniku ich ojciec [E:391]. Anegdoty, legendy czy rodzinne etiologie wyjaśniające zwyczaje te pomyślne i te złowróżebne przenikają opowieści o krakowskich rodach, ale przede wszystkim stanową narracyjny trzon międzygeneracyjnego przekazu. I tak, tradycyjny zakaz kąpieli 29 czerwca równoważy szczęśliwa dla Zollów data 18 kwietnia, skądinąd niemniej szczęśliwa dla Stuhrów skoro w tym właśnie dniu 1947 roku urodził się Tadeuszowi i Marii „Rysi” z Chorążych - syn, późniejszy aktor Starego Teatru w Krakowie. Owe osobliwości faktyczne lub mityczne zostały spisane dla przyszłych kontynuatorów tradycji wielkich rodów, ale także dla czytelników zainteresowanych historią życia codziennego mieszkańców Krakowa na przestrzeni wieków. Sagi rozpoznawalnych krakowskich rodów, mimo, a może właśnie dlatego, że spisane przez osoby zaangażowane, nieobiektywne same pełnią rolę wizytówki 
„Polskiej Jerozolimy”. Osobnym tematem, przekraczającym jednak ramy tego artykułu, będzie problem kontaktów, relacji i stosunków między krakowskimi rodzinami, a zatem sfera życia towarzyskiego, którą w swoim czasie podjęła Maria Estraicherówna [Estraicherówna 1936, 1968].

Ważne, że w kulturze emocjonalnego ekshibicjonizmu analizowane sagi rodzinne nie wpisują się w krąg tabloidowych narracji. Problem subtelnych granic prywatności i „afiszowania się w mediach” wyraził expressis verbis Jerzy Stuhr:

Przed laty zawarliśmy pakt o ochronie naszej prywatności. Układ, by jak najmniej mówić o rodzinie. Dopiero ta książka po raz pierwszy uchyla drzwi do naszego prywatnego życia. Uznaliśmy, że tym razem nie chodzi o wywlekanie prywatności, ale o pokazanie, jakie wartości budują na stałe w człowieku to, co najważniejsze. (...) W jaki sposób wiedza o rodzinie, o ojcach, dziadkach i pradziadkach warunkuje nasze zachowania [S:259-261].

W ten sposób przywołane sagi rodzinne, bazujące na wspomnieniach, pamiętnikach, dziennikach, innych dokumentach prywatnych archiwów, doświadczeniach i przeżyciach przekazywanych dzięki żywej pamięci, a po latach spisane, stają się przykładem kulturowej skuteczności i nieprzeliczalnej wartości więzów wielopokoleniowych [Bieńko 2007].

W kontekście strategii promocji [o kontrowersjach związanych z kampanią promocyjną Krakowa Gołębie kręca Kraków z udziałem aktora i jego opinii o krytyce, zob. Stuhr 2012: 72-75] i zapisu na stronach Urzędu Miasta Krakowa:

W promocji wizerunkowej podstawowym celem strategicznym jest budowanie silnej marki «Kraków». Należy stworzyć opis wyjątkowości Krakowa, tego co odróżnia Kraków od innych miast (...) i korzystać zeń przy wszystkich działaniach promocyjnych. Trzeba określić (bądź stworzyć) listę symboli i produktów kojarzonych z Krakowem. (znajdą się tu marki, symbole, instytucje i wydarzenia artystyczne, na przykład hejnał mariacki, obwarzanki, Rynek, Uniwersytet Jagielloński, Festiwal Kultury Żydowskiej,) Kraków powinien być promowany jako marka narodowa" [Budowanie silnej 2014. Pisownia jak w oryginale]

warto pamiętać, że przede wszystkim ludzie stanowią o wizerunku, wizytówce czy, jak chcą współcześni włodarze, „marce” miasta, w tym przypadku Krakowa. 


\section{Bibliografia}

„Alma Mater” (2009), Aresztowani 6 listopada 1939 roku podczas Sonderaktion Krakau // Persons arrested on 6 November 1939 under Sonderaktion Krakau, nr 118: 19

„Diabeł” (1912), R. 45, (1 III), nr 5, Kronika krakowska: 8

Bielas-Gołubowska U. (2011), Saga polska, czyli „Zoll, kto ty jesteś?”, „Pogranicza” 2: 117-120

Bieniarzówna J., Małecki J., Mitkowski J., (1979), Dzieje Krakowa, t. 3: Kraków w latach 17961918, Kraków

Bieńko M. (2007), Znaczenie więzi wielopokoleniowych, „Problemy Opiekuńczo-Wychowawcze” R. 47, nr 9: 3-11

Bieńkowski W. (1983), Rola Krakowa w polskim życiu naukowym, [w:] J. Małecki (red.), Kraków na przełomie XIX i XX wieku. Materiały z sesji naukowej z okazji dni Krakowa w 1981 roku, Kraków: $19-44$

Boy-Żeleński T. (1967), O Krakowie, oprac. H. Markiewicz, Kraków

Budowanie silnej marki „Kraków”, http://www.bip.krakow.pl/?sub_dok_id=459 [17.01.2014]

Burkot S. (2005), Uwertura i niespetnienie, „Małopolska” t. 7: 61-75

Chojecka E. (2011), Trzy modele kulturowej pamięci: Kraków, Katowice, Wrocław // Three models of cultural memory: Kraków, Katowice, Wrocław, tłum. T. Bieroń, „Herito” R. 1, nr 2: 78-87

Cieński A. (1992), Pamiętniki i autobiografie światowe, Wrocław-Warszawa-Kraków

Czabanowska-Wróbel A. (2011), Palimpsest Krakowa z przełomu XIX i XX wieku - ślady przeszłości i znaki tego, co nowe, [w:] K. Fiołek, M. Stala (red.), Kraków i Galicja wobec przemian cywilizacyjnych (1866 - 1914). Studia i szkice, Kraków: 345-362

Demel J. (1957), Kraków na przełomie wieku XIX i XX na tle rozwoju i wcielenia przedmieść i gmin podmiejskich 1867-1945, [w:] J. Dąbrowski (red.), Kraków. Studia nad rozwojem miasta, Kraków: 287-351

Dybiec J. (2007), Kraków w narodowej pamięci, „Palestra” R. 52, nr 11-12: 145-151

Estreicher K. (2001), Dziennik wypadków, t. 1: 1939-1945, Wstęp Z.K. Witek, Kraków

Estreicher K. (2002), Dziennik wypadków, t. 2: 1946-1960; Wstęp Z.K. Witek, (red.) A.M. Joniak, Kraków

Estreicher K. (2003), Dziennik wypadków, t. 3: 1961-1966; Wstęp Z.K. Witek, (red.) A.M. Joniak, Kraków

Estreicher K. (2004), Dziennik wypadków, t. 4: 1967-1972, Wstęp Z.K. Witek, (red.) A.M. Joniak, Kraków

Estreicher K. (2006), Dziennik wypadków, t. 5: 1973-1977; Wstęp Z.K. Witek, (red.) A.M. Joniak, Kraków

Estreicher K. (2013), Dziennik wypadków, t. 6: 1978-1980, Wstęp Z.K. Witek, (red.) A.M. Joniak, Kraków

Estreicherówna M. (1936), Życie towarzyskie i obyczajowe Krakowa w latach 1848-63, t. 1-2, Kraków (Biblioteka Krakowska 91, 92)

Estreicherówna M. (1968), Życie towarzyskie i obyczajowe Krakowa w latach 1848-1863, (red.) i dobór ilustracji J. Pociecha, Kraków

Estreicherówna M. (1999), Wybór z „Dziennika” Marii Estreicherówny z lat 1886-1938, oprac. M. Świątecka, „Rocznik Biblioteki Polskiej Akademii Nauk w Krakowie” R. 44: 233-292

Giddens A. (2001), Nowoczesność i tożsamość. „Ja” i społeczeństwo w epoce późnej nowoczesności, tłum. A. Szulżycka, Warszawa 
Głowiński M. (1997), Stanisława Pigonia relacja o Sachsenhausen, [w:] tegoż, Narracje literackie i nieliterackie, Kraków: 148-158

Głowiński M. i in. (1988), Słownik terminów literackich, Wrocław

Grodziska K. (2003), „Gdzie miasto zaczarowane...”. Księga cytatów o Krakowie, Kraków

Grodziski S. (1998), Stanisław Estreicher jako twórca porównawczej historii państwa i prawa, „Czasopismo Prawno-Historyczne” t. 50, z. 1: 117-128

Grzybowska K. (1957), Szałas, „Dialog” R. 2, nr 12 (20): 25-45

Grzybowska K. (1959), Penelopa i mandarynki. Reportaż z podróży po Grecji, Warszawa

Grzybowska K. (1960), Zuzia, Warszawa (także: 1962, 1968)

Grzybowska K. (1961), Julian czyli o końcu świata. Żart z pewnym sensem, Kraków

Grzybowska K. (1962), I ja i Franuś, Warszawa (także: 1982)

Grzybowska K. (1969), Kronika rodzinna, Wrocław

Grzybowska K. (2010) - skrót E, Estreicherowie. Kronika rodzinna, Kraków (także 1999)

Grzybowski S. (2010), O autorce, [w:] K. Grzybowska, Estreicherowie. Kronika rodzinna, Kraków: 462-466

Gwiazdomorski J. (1964), Szkoła teleologiczna. Fryderyk Zoll młodszy 1865-1948, [w:] M. Patkaniowski (red.), Studia z dziejów Wydziału Prawa Uniwersytetu Jagiellońskiego, Kraków: 287-296 (Zeszyty Naukowe Uniwersytetu Jagiellońskiego 100, Prace Prawnicze 18)

Gwiazdomorski J. (1964a), Wspomnienia z Sachsenhausen. Dzieje uwięzienia profesorów Uniwersytetu Jagiellońskiego 6 listopada 1939-9 lutego 1940, Kraków

Homola I. (1984), „Kwiat społeczeństwa” (Struktura społeczna i zarys położenia inteligencji krakowskiej w latach 1860-1914), Kraków-Wrocław

Homola Skąpska I. (1996), „Das Klaine Wien” an der Weichsel, Übersetzt von M. Smykała, [w:] J. Hrycyk (red.), Österreich - Polen. 1000 Jahre Beziehungen, Kraków, (Deutsche Fassung), s. 459-480 Zeszyty Naukowe Uniwersytetu Jagiellońskiego, Prace Historyczne 121, Studia Austro-Polonica 5

Homola Skąpska I. (1997), „Mały Wiedeñ” nad Wisłą, [w:] J. Buszko, W. Leitsch, J. Rydel (red.), Austria - Polska. 1000 lat kontaktów, Kraków (wersja polska), s. 409-426 (Zeszyty Naukowe Uniwersytetu Jagiellońskiego, Prace Historyczne 121, Studia Austro-Polonica 5)

Kantor R. (1994), Kraków - wielka scena narodowego teatru, [w:] R. Godula (red.), Klejnoty i sekrety Krakowa. Teksty $z$ antropologii miasta, Kraków, s. 37-62

Karpińska H.M. (2009), Dynastia Stuhrów, [rec. J. Stuhr, Stuhrowie. Historie rodzinne, Kraków 2008] „Nowe Książki” 3: 45

Klich-Kluczewska B. (2005), Przez dziurke od klucza. Życie prywatne w Krakowie (1945-1989), Warszawa

Konopczyński W. (1945), Pod trupią główką (Sonderaktion Krakau), „Tygodnik Powszechny” R. 1, nr 3 (8 IV): 3-4; nr 4 (15 IV): 3-4; nr 5 (22 IV): 3; nr 6 (29 IV): 3-4; nr 7 (6 V): 2-3; nr 8 (13 V): 3; nr 9 (20 V): 3; nr 10 (27 V): 3; nr 11 (3 VI): 3; nr 12 (10 VI): 3; nr 13 (17 VI): 3; nr 14 (24 VI): 3; nr 15 (1 VII): 4-5; nr 16 (8 VII): 4-5; nr 17 (15 VII): 4-5

Korczak J. (2000), Estreicherowie, [rec. K. Grzybowska, Estreicherowie. Kronika rodzinna, Kraków 1999] „Arkusz”, nr 4 (101): 8

Kubicki P. (2010), Miasto w sieci znaczeń. Kraków i jego tożsamości, Kraków

Kubicki P. (2012), Pomiędzy pamięcią a historia. Polskie miasta wobec wielokulturowego dziedzictwa, „Pogranicze. Studia Społeczne” t. 20: 53-66 
Kusek R. (2008), „Wielki Kraków” czy „Pipidówka” - opis wyglądu miasta za czasów Juliusza Leo zarysowany na łamach czasopisma humorystycznego „Diabet”, „Krakowski Rocznik Archiwalny" 14: 61-106

Landau L. (1962), Kronika lat wojny i okupacji, t. 1: Wrzesień 1939 - listopad 1940, Warszawa

Lejeune S. (2007), Wariacje na temat pewnego paktu. O autobiografii, Kraków

Mikołajec J. (2007), Wrocław, Kraków, Lwów - miasta środkowoeuropejskiego szlaku, „Nurt SVD” R. 41: 2007, z. 3-4: 181-192

Miliszkiewicz J. (2009), Estreicherowie, „Spotkania z Zabytkami” R. 33, nr 7: 30-31

Morawski P. (2011), Uczeni, rektorzy, żołnierze, [rec. A. Zoll, Zollowie. Opowieść rodzinna, Kraków 2011] „Nowe Książki” 4: 9-10

Mroczka L. (1999), Krakowianie. Szkice do portretu zbiorowego w dobie industrialnej transformacji 1890-1939, Kraków

Niedźwiedź A. (2006), Kraków - „miasto papieskie”. Analiza symboliki i mitologii przestrzeni miejskiej, "Journal of Urban Ethnology" 8: 25-45

Obarska M. (2008), Adwokat autobiografii, [rec. P. Lejeune, Wariacje na temat pewnego paktu. O autobiografii], „Kultura i Społeczeństwo” t. 52, nr 1: 145-148

Owsiany E. (1996), Ostatni z dynastii Estreicherów, „Sycyna” 12: 5

Pigoń S. (1966), Wspominki z obozu w Sachsenhausen (1939-1940), Warszawa

Piwarski K. (1946), Straty nauki polskiej w Krakowie, [w:] J. Dąbrowski (red.), Kraków pod rządami wroga 1939-1945, Kraków: 66-93 (Biblioteka Krakowska, 104)

Pochłódka A. (2008), Życie kulturalne krakowskich mieszczan przełomu XIX i XX wieku w zapiskach autobiograficznych - zarys problematyki, „Teksty Drugie” nr 3: 194-200

Purchla J. (1992), Matecznik Polski. Pozaekonomiczne czynniki rozwoju Krakowa w okresie autonomii galicyjskiej, Kraków

Radomski A. (2005), Wielkie narracje a mikronarracje - etyczne dylematy współczesnego pisarstwa historycznego, [w:] L. Koczanowicz, R. Nahirnym, R. Włodarczyk (red.), Narracje - (Auto) biografia - Etyka, Wrocław: 243-253

Röskau-Rydel I. (2011), Niemiecko-austriackie rodziny urzędnicze w Galicji 1772-1918. Kariery zawodowe, środowisko, akulturacja i asymilacja, Kraków, (Prace Monograficzne, Uniwersytet Pedagogiczny im. Komisji Edukacji Narodowej w Krakowie, 588)

Starachowicz A. (2012), Sonderaktion Krakau. Wspomnienia z akcji przeciwko profesorom uniwersyteckim w Krakowie (6-10 listopada 1939 roku), wstęp i oprac. K. Starachowicz, F. Wasyl, Gdańsk

Stuhr J. (1992), Sercowa choroba, czyli moje życie w sztuce, Warszawa

Stuhr J. (2007), Ucieczka do przodu! Jerzy Stuhr od A do Zw wywiadach Marii Malatyńskiej, Kraków

Stuhr J. (2008) - skrót S, Stuhrowie. Historie rodzinne, oprac. A. Pawlicka, Kraków

Stuhr J. (2012), Tak sobie myślę... Dziennik czasu choroby, Kraków

Tazbir J. (2000), Saga wielkiego rodu, [rec. K. Grzybowska, Estreicherowie. Kronika rodzinna, Kraków 1999], „Nowe Książki” 4: 26-27

Ulewicz T. (1994), Kraków - polski Rzym (jak, kiedy, dlaczego). Gawęda przysłowioznawcza, [w:] R. Godula (red.), Klejnoty i sekrety Krakowa. Teksty z antropologii miasta, Kraków: 63-76

Urbańczyk S. (1946), Uniwersytet za kolczastym drutem (Sachsenhausen - Dachau), Kraków, 1969 
Uruszczak W. (2007), Znaczenie Krakowa w rozwoju polskiej kultury prawnej, „Palestra” R. 52, nr 11-12: 152-162

Waksmund R. (2009), Kraków w pamięci dzieciństwa. Przyczynek do topiki wspomnieniowej, [w:] A. Baluch, M. Chrobak, M. Rogoża (red.), Kraków magiczny. Motywy, wątki, obrazy w utworach dla dzieci i młodzieży, Kraków: 157-169

Wójs R. (2009), Artysta w mieście. Przestrzeń Krakowa w prozie Jerzego Pilcha, „Orbis Linguarum” 35: 351-358

Ziejka F. (2010), Serce Polski. Szkice krakowskie, Kraków 2010, s. 11-40; także [w:] tegoż, Tu wszystko jest Polska... (O roli Krakowa w życiu duchowym Polaków w wieku XIX), „Rocznik Krakowski” 1996, t. 62: 31-50

Znaniecki F. (1970), Znaczenie dokumentów autobiograficznych dla badań socjologicznych, „Kultura i Społeczeństwo" 3, s. 117-127; przedruk z: F. Znaniecki, Przedmowa, [w:] W. Berkan, Życiorys własny, Poznań 1924: III-XVII

Zoll A. (2011) - skrót Z, Zollowie. Opowieść rodzinna, współpraca J. Zoll, Kraków

Zoll A. (2011), Nie tylko o tym, co było, rozm. przepr. M. Borczak, „Nowe Książki” 4: 4-8

Zoll F. (2000), Wspomnienia Fryderyka Zolla (1865-1948), oprac. I. Homola Skąpska, Kraków 


\section{SUMMARY}

\section{The Family as a Recognized Symbol of the City. Krakow Case}

This article is dedicated to three Cracovian families, very recognizable in the Polish society: the Estreichers, the Zolls and the Stuhrs. The (auto)biographical stories written by the representatives of those families became the basis for the analysis of their relation with Krakow. Three selected cases have many characteristics in common such as a strong sense of their family identity, public activities of many members of the families, their connections with Krakow as an academic, cultural and scientific center which are accented with emphasis. Those cases are the great examples of the best recognized symbol of the city (which is earnestly sought by the local government and the creators of brands of the city), that is a human. From this point of view, man is shown as a member of his basic environment which is the family (home).

\section{Keywords:}

family, Krakow, city, Estreicher, Zoll, Stuhr 